\title{
KOMPENSASI DAN KEPUASAN KERJA SEBAGAI ALTERNATIF PENINGKATAN KINERJA KARYAWAN
}

\author{
Nailin Nikmatul Maulidiyah ${ }^{1}$ Tri Nadhirotur Roifah ${ }^{2}$ Nuruddin Armanto ${ }^{3}$ \\ Universitas Islam Zainul Hasan Genggong Probolinggo
}

\begin{abstract}
ABSTRAKC
This study aims to determine the effect of compensation on employee performance and the effect of job satisfaction on employee performance. This research is a qualitative research which is sourced from existing theories and relevant empirical research journals. The results of this study showed that compensation has a positive effect on employee performance and job satisfaction has a positive effect on employee performance.

Keywords: Compensation; Job satisfaction ; Performance
\end{abstract}

\section{PENDAHULUAN}

Persaingan di dunia bisnis saat ini sudah semakin ketat. Perusahaan selalu dihadapkan dengan persaingan yang semakin kompetitif, dalam menghadapi perusahaan pesaing tentunya tidak cukup hanya dengan menggunakan teknologi dalam kegiatan operasionalnya. Penggunaan teknologi canggih pada perusahaan harus didukung oleh sumber daya manusia yang berkualitas, sebab secanggih apapun teknologi yang digunakan oleh perusahaan apabila tidak ditunjang dengan sumber daya manusia yang berkualitas dan kompeten maka hal tersebut tidak akan memberikan kontribusi positif dalam menjamin kelancaran operasional perusahaan. Sumber daya manusia yang dimiliki perusahaan memiliki peranan yang sangat penting dalam menjalankan kegiatan operasional. Karyawan mempunyai peran kunci dalam setiap kegiatan perusahaan. Kinerja yang dimilki oleh karyawan dituntut untuk semakin meningkat. Salah satu upaya untuk meningkatkan kualitas kinerja karyawan adalah mengevaluasi kinerja karyawan dan melakukan berbagai langkah perbaikan agar kualitas karyawan meningkat sehingga perusahaan dapat berkembang dan memiliki keunggulan tersendiri dalam persaingan dengan perusahaan-perusahaan lain. Perusahaan yang selalu memantau dan mengevaluasi kinerja karyawannya secara rutin akan menjadi lebih unggul dengan pesaing-pesaing bahkan bisa menguasai pasar yang ada. Perusahaan apat memperoleh keuntungan maksimal apabila kinerja karyawannya 
meningkat, sebaliknya apabila kinerja yang turun dapat mengakibatkan perusahaan mengalami kerugian. Oleh karena itu, tujuan perusahaan harus dapat dicapai dengan tepat sesuai dengan perencanaan perusahaan. Menurut Mangkunegara (2006:67) kinerja merupakan hasil kerja secara kualitas dan kuantitas yang dicapai oleh seorang karyawan dalam melaksanakan tugas sesuai dengan tanggung jawab yang diberikan kepadanya. Upaya untuk meningkatkan kinerja karyawan juga dipengaruhi oleh banyak faktor diantaranya adalah kompensasi dan kepuasan kerja.

Salah satu faktor yang menjadi dapat mendorong peningkatan kinerja karyawan adalah kepuasan kerja. Kepuasan kerja karyawan harus diperhatikan dengan baik oleh perusahaan karena merupakan faktor kunci dalam mensukseskan peningkatan prestasi dan kinerja karyawan perusahaan. Menurut Handoko (2006 : 193) kepuasan kerja adalah keadaan emosional yang menyenangkan atau tidak menyenangkan dengan mana karyawan memandang pekerjannya. Semakin tinggi kepuasan kerja karyawan, maka kinerjanya akan semakin meningkat.

Faktor lain yang mempengaruhi kinerja adalah kompensasi. Simamora (2004:155) menyatakan bahwa kompensasi merupakan apa yang diterima oleh para karyawan sebagai ganti kontribusi mereka kepada organisasi. Pemberian kompensasi merupakan sesuatu yang wajib dilakukan oleh semua perusahaan atau organisasi atas jerih payah yang telah dilakukan oleh para karyawannya. Tingkat kompensasi yang diberikan perusahaan kepada karyawannya akan mempengaruhi psikologi dari karyawan tersebut. Kompensasi yang layak akan memberikan kepuasan kerja bagi karyawan sehingga kinerjanya dapat terus meningkat.

\section{LANDASAN TEORI}

\section{Kompensasi}

Simamora (2004:155) menyatakan bahwa kompensasi merupakan apa yang diterima oleh para karyawan sebagai ganti kontribusi mereka kepada organisasi. Menurut Hasibuan (2003:133), kompensasi adalah semua pendapatan yang berbentuk uang atau barang langsung yang diterima karyawan sebagai imbalan atau jasa yang diberikan kepada perusahaan. 
Mondy (2008:5) mengemukakan bahwa kompensasi memiliki dua komponen yaitu:

a. Kompensasi finansial, yaitu total seluruh imbalan yang diterima karyawan sebagai pengganti jasa mereka. Kompensasi finansial dibedakan ke dalam dua komponen, yaitu: kompensasi finansial langsung dan kompensasi finansial tidak langsung. Kompensasi finansial langsung adalah bayaran yang diterima seseorang dalam bentuk upah, gaji, komisi atau bonus. Sedangkan kompensasi finansial tidak langsung adalah seluruh imbalan finansial yang tidak termasuk dalam kompensasi finansial langsung seperti tunjangan.

b. Kompensasi non finansial, yaitu kepuasan yang diterima seseorang dari pekerjaan itu sendiri atau dari lingkungan psikologis dan/atau fisik tempat orang tersebut bekerja.

Menurut Hasibuan (2013:121), tujuan pemberian kompensasi adalah sebagai berikut:

a. Ikatan kerja sama

Melalui pemberian kompenasasi terjalinlah ikatan kerja sama formal antara atasan dengan bawahan.

b. Kepuasan kerja

Melalui balas jasa, karyawan akan dapat memenuhi kebutuhan-kebutuhan fisik, status sosial, dan egoitiknya sehingga memperoleh kepuasan kerja dari jabatannya.

c. Pengadaan efektif

Jika program kompensasi ditetapkan cukup besar, pengadaan karyawan yang qualified perusahaan akan lebih mudah.

d. Motivasi

Jika balas jasa yang diberikan cukup besar, manajer akan mudah memotivasi bawahannya.

e. Stabilitas karyawan

Melalui program kompensasi atas prinsip adil dan layak serta eksternal konsistensi yang kompetatif maka stabilitas karyawan lebih terjamin karena turn-over relatif kecil. 


\section{f. Disiplin}

Melalui pemberian balas jasa yang cukup besar maka disiplin karyawan semakin baik.

g. Pengaruh serikat buruh

Melalui program kompensasi yang baik pengaruh serikat buruh dapat dihindarkan dan karyawan akan berkonsentrasi pada pekerjaanya.

h. Pengaruh pemerintah

Jika program kompensasi sesuai dengan undang-undang perburuan yang berlaku (seperti batas upah minimum) maka intervensi pemerintah dapat dihindarkan.

\section{Kepuasan Kerja}

Menurut Handoko (2006 : 193) kepuasan kerja adalah keadaan emosional yang menyenangkan atau tidak menyenangkan dengan mana karyawan memandang pekerjannya. Menurut Robbins (2003:91) istilah kepuasan kerja merujuk kepada sikap umum seorang individu terhadap pekerjaan yang dilakukannya. Seseorang dengan tingkat kepuasan kerja tinggi menunjukkan sikap yang positif terhadap pekerjaannya, sedangkan seseorang yang tidak puas dengan pekerjaannya menunjukan sikap yang negatif terhadap pekerjaan itu.

Menurut John dan Michael (2007;90), indikator kepuasan kerja antara lain:

a. Pembayaran gaji

Jumlah pembayaran yang diterima dan tingkat kesesuaian antara pembayaran tersebut dengan pekerjaan yang dilakukan.

b. Pekerjaan itu sendiri

Sejauh mana pekerjaan itu dianggap menarik, menyediakan kesempatan untuk belajar dan membrikan tanggung jawab.

c. Rekan kerja

Sejauh mana rekan kerja bersahabat, kompeten, dan memberikan dorongan dan dukungan dalam bekerja.

d. Promosi jabatan

Ketersediaanya peluang promosi untuk lebih maju penempatan dalam bekerja.

\section{e. Supervisi}

Kompetensi teknis dan ketrampilan interpersonal dari atasan langsung.

f. Kondisi pekerjaan 
Sejauh mana lingkungan kerja fisik maupun non fisik memberikan kenyamanan dan memndukung produktifitas dalam bekerja.

\section{Kinerja}

Menurut Mangkunegara (2006:9) kinerja merupakan hasil kerja secara kualitas dan kuantitas yang ducapai oleh seseorang pegawai dalam melaksanakan tugasnya sesuai dengan tanggung jawab yang diberikan kepadanya. Menurut Rivai (2004:309) mengatakan pengertian kinerja adalah merupakan perilaku nyata yang ditampilkan setiap orang sebagai prestasi kerja yang dihasilkan oleh karyawan sesuai dengan perannya dalam perusahaan serta kinerja karyawan merupakan suatu hal yang penting dalam upaya perusahaan untuk mencapai tujuannya.

Faktor-faktor yang mempengaruhi kinerja menurut Mangkunegara (2009:67) adalah sebagai berikut:

a. Kemampuan (Ability)

Faktor kemampuan, secara psikologis kemampuan (abitity) pegawai terdiri dari kemampuan potensi (IQ) dan kemampuan realita (pendidikan). Oleh karena itu pegawai perlu ditempatkan pada pekerjaan yang sesuai dengan keahliannya

b. Motivasi (Motivation)

Faktor motivasi, motivasi terbentuk dari sikap (atitude) seorang pegawai dalam menghadapi situasi kerja. Motivasi merupakan kondisi yang menggerakkan diri pegawai yang teararah untuk mencapai tujuan organisasi.

Menurut Mangkunegara (2009:67) indikator yang bisa digunakan dalam menilai kinerja karyawan adalah :

a. Kualitas kerja

Menunjukkan kerapihan, ketelitian, keterkaitan hasil kerja dengan tidak mengabaikan volume pekerjaan. Adanya kualitas kerja yang baik dapat menghindari tingkat kesalahan dalam penyelesaian suatu pekerjaan yang dapat bermanfaat bagi kemajuan perusahaan.

b. Kuantitas kerja Menunjukkan banyaknya jumlah jenis pekerjaan yang dilakukan dalam suatu waktu sehingga efisiensi dan efektivitas dapat terlaksana sesuai dengan tujuan perusahaan.

c. Tanggung jawab 
Menunjukkan seberapa besar karyawan dalam menerima dan melaksanakan pekerjaannya, mempertanggungjawabkan hasil kerja serta sarana dan prasarana yang digunakan dan perilaku kerjanya setiap hari.

d. Kerjasama

Menunjukkan kesediaan karyawan untuk berpartisipasi dengan karyawan lain secara vertikan dan horizontal baik di dalam maupun di luar pekerjaan sehingga pekerjaan akan semakibaik.

e. Inisiatif

Adanya inisiatif dalam diri anggota organisasi untuk melakukan pekerjaan serta mengatasi masalah dalam pekerjaan merupakan cara seseorang karyawan yang memiliki kinerja yang baik. Sehingga tanpa menunggu perintah dari atasan, karyawan mampu mengatasi masalah dalam melakukan pekerjaan dengan baik.

\section{METODOLOGI PENELITIAN}

Penelitian ini menggunakan pendekatan kualitatif dengan pendekatan kajian pustaka yang bersumber dari teori - teori yang ada dan jurnal - jurnal penelitian terdahulu yang relevan dengan penelitian ini.

\section{HASIL DAN PEMBAHASAN}

\section{Pengaruh Kompensasi terhadap Kinerja Karyawan}

Simamora (2004:155) menyatakan bahwa kompensasi merupakan apa yang diterima oleh para karyawan sebagai ganti kontribusi mereka kepada organisasi. Kompensasi adalah semua pendapatan yang berbentuk uang, barang langsung atau tidak langsung yang diterima karyawan sebagai imbalan atas jasa yang diberikan kepada perusahaan (Hasibuan, 2003:54). Hubungan kompensasi dan kinerja sebenarnya saling berkaitan. Antara kompensasi dan kinerja karyawan. Pembayaran kompensasi dapat memberi dampak positif dan negatif. Ketika pembayaran kompensasi tinggi dan sesuai dengan tanggung jawab yang diberikan kepada karyawan dapat memberi dampak positif dalam meningkatkan kinerja. Sebaliknya, ketika kompensasi yang diterima karyawan tidak layak dan tidak sesuai dengan tugas dan tanggung jawab yang dibebankan kepada karyawan, maka akan menyebabkan karyawan tersebut menjadi kurang termotivasi, merasa frustasi dan hasil kerjanya akan tidak optimal. Kebijakan pemberian kompensasi yang tepat dan diterima oleh karyawan akan meningkatkan kinerja karyawan dengan baik. Maka dari itu, kompensasi yang tinggi diharapkan dapat meningkatkan kualitas, 
produktifitas, serta kinerja menjadi lebih tinggi. Kompensasi berpengaruh positif terhadap kinerja karyawan. Artinya, semakin tinggi kompensasi yang diterima karyawan maka kinerjanya akan semakin tinggi pula. Sebaliknya, semakin rendah kompensasi yang diterima karyawan maka akan semakin rendah pula kinerja karyawan tersebut.

\section{Pengaruh Kepuasan Kerja terhadap Kinerja Karyawan}

Menurut Handoko (2006 : 193) kepuasan kerja adalah keadaan emosional yang menyenangkan atau tidak menyenangkan dengan mana karyawan memandang pekerjannya. Kepuasan kerja memiliki hubungan langsung terhadap kinerja karyawan dalam suatu organisasi. Hariandja (2009:290) menyatakan bahwa kepuasan kerja merupakan salah satu faktor yang memiliki peranan dalam organisasi. Karyawan yang mempunyai kepuasan kerja tinggi akan termotivasi untuk bekerja lebih giat lagi sehingga kinerjanya akan semakin meningkat. Begitu juga sebaliknya, apabila karyawan tidak mendapatkan kepuasan dalam bekerja, maka hasil kerjanya juga tidak akan optimal. Oleh karena itu, kepuasan kerja karyawan harus betul-betul diperhatikan oleh perusahaan dan harus dijaga agar kinerja karyawan menjadi lebih maksimal. Ketika kepuasan karyawan dalam bekerja dapat tercapai, maka kinerjanya juga akan meningkat. Secara umum, karyawan yang mendapatkan kepusan kerja akan melaksanakan pekerjaannya dengan baik. Apabila penghargaan yang diberikan perusahaan kepada karyawan dirasa adil dan memadai, maka kepuasan kerja karyawan akan meningkat karena mereka menerima penghargaan yang sesuai dengan prestasi kerja mereka. Berdasarkan beberapa pengertian diatas dapat dikatakan bahwa kepuasan kerja karyawan berpengaruh positif terhadap kinerja karyawan. Semakin tinggi kepuasan kerja karyawan, maka kinerjanya akan semakin tinggi pula. Sebaliknya, semakin rendah kepuasan kerja karyawan maka akan semakin rendah pula kinerja karyawan tersebut.

\section{KESIMPULAN}

Kompensasi berpengaruh positif terhadap kinerja karyawan. Artinya, semakin tinggi kompensasi yang diterima karyawan maka kinerjanya akan semakin tinggi pula. Sebaliknya, semakin rendah kompensasi yang diterima karyawan maka akan semakin rendah pula kinerja karyawan tersebut. 
Kepuasan kerja berpengaruh positif terhadap kinerja karyawan. Artinya, semakin tinggi kepuasan kerja karyawan, maka kinerjanya akan semakin tinggi pula. Sebaliknya, semakin rendah kepuasan kerja karyawan maka akan semakin rendah pula kinerja karyawan tersebut.

\section{DAFTAR PUSTAKA}

Handoko, T. Hani.2006. Manajemen Personalia dan Sumber Daya Manusia. Yogyakarta: BPFE.

Hariandja, Marihot Tua Efendi. 2009. Manajemen Sumber Daya Manusia, Pengadaan, Pengembangan, Pengkompensasian, dan Peningkantan Produktifitas Pegawai. Jakarta: Grasindo.

Hasibuan, Malayu S.P. 2003. Manajemen Sumber Daya Manusia. Jakarta: Bumi Aksara.

John, Robert dan Michael. 2007. Perilaku dan Manajemen Organisasi. Jakarta : Erlangga.

Mangkunegara, AA. Anwar Prabu. 2006. Manajemen Sumber Daya Manusia. Bandung: Remaja Rosdakarya.

Mondy, R. Wayne. 2008. Manajemen Sumber Daya Manusia. Jakarta: Erlangga.

Rivai, Veitzhal. 2004. Manajemen Sumber Daya Manusia untuk Perusahaan. Jakarta: Murai Kencana.

Robbins, Stephen P. 2003. Perilaku Organisasi. Jakarta: PT. Indeks Kelompok Gramedia

Simamora, Henry. 2004. Manajemen Sumber Daya Manusia. Edisi Ketiga. Yogyakarta: STIE YKPN. 